\title{
GEOCHEMICAL ANALYSES OF RECENT SEDIMENTS FROM LAKE MORZYCKO AGAINST SELECTED PHYSIOGRAPHIC PARAMETERS OF THE SLUBIA RIVER CATCHMENT (WESTERN POLAND)
}

\author{
ANNA ADAMEK', PAULINA MARECZKA², WITOLD JUCHA², \\ STANISŁAW MUSIELAK ${ }^{3}$, DANIEL OKUPNY
}

\begin{abstract}
This paper presents the results of a study on the content of lithogeochemical components (organic matter, $\mathrm{Na}, \mathrm{K}$, $\mathrm{Mg}, \mathrm{Ca}, \mathrm{Mn}, \mathrm{Fe}, \mathrm{Cu}$ and $\mathrm{Zn}$ ) and grain-size composition of mineral matter in the bottom sediments of Morzycko Lake (Myślibórz Lakeland, NW Poland). This lake is large (342.7 ha) and deep (69 m). The catchment has a typical forested character (mainly in the middle part of the Stubia River valley) with agricultural area (mainly in the upland areas north of the lake). The diversity of concentrations of metals was analysed based on 44 samples from 22 representative sites, including surface sediments and sediments from $5 \mathrm{~cm}$ below the current lake bed. The results showed that the chemical composition and granulometry of bottom sediments depends on contemporary morphogenetic processes in the catchment of the Słubia River. Geochemical and grain-size indices varied due to changes in biological productivity, intensity of weathering of postglacial material making up the catchment, and potential for migration of metals to the lake with surface or underground runoff. An important aspect in assessing the degree of enrichment of the sediments in trace elements is the location of shallow parts of the lake near the tourist districts of Moryń.
\end{abstract}

Key words: lake sediments, geochemistry, grain-size composition, land-cover photointerpretation, Myślibórz Lakeland

\section{Introduction}

Lakes exemplify complex ecosystems varying with respect to their area, depth, shoreline type, water chemistry and thermal conditions. Sediment accumulation, including terrigenous material supply via rivers, which carry large volumes of mostly mineral suspension, is responsible for a gradual decrease in lake depth and surface area. The history of the lake and how its environment has been changing through time may be learned from studying the bottom sediments. Moreover, the growing interest in lake sediments among Earth scientists and archaeologists is due to the growing support for distinguishing the Anthropocene as the most recent period in Earth's history (Wolfe et al. 2013). Further, there is a broad consensus that lake sediments document the history of changes in various elements of the environment, including human impact, both prehistoric and contemporary (Tobolski
2004; Florek, Majewski 2008; Kittel et al. 2021). Among the numerous methods applied in natural sciences, geochemistry plays an important part, as it gives a comprehensive insight into, among other things, hydroclimatic and geomorphological changes, as well as the succession of settlements and cultures contributing to the regional or local geochemical background of a given area (Gałuszka 2006; Borówka 2007; Zgłobicki 2010; Szwarczewski, Smolska 2013). One of the main aims of geochemical studies on lake bottom sediments is to determine quantitative relationships between autochthonous and allochthonous components, which in turn enables a reconstruction of environmental changes taking place not only within the lake itself, but also within its catchment (Rutkowski 2007; Więckowski 2009).

Factors controlling sedimentation rate and chemical composition of lake sediments include predominantly: climate, geology and lithology of

\footnotetext{
${ }^{1}$ School Complex in Moryń, Dworcowa 6a, 74-503 Moryń

2 Pedagogical University of Cracow, Institute of Geography, Podchorążych 2, 30-084 Kraków, Poland; Witold Jucha ORCID: 0000-0002-2204-8721

${ }^{3}$ University of Szczecin, Institute of Marine and Environmental Science, Adama Mickiewicza 18, 70-383 Szczecin, Poland, Stanisław Musielak ORCID: 0000-0002-4770-1432; Daniel Okupny e-mail: daniel.okupny@usz.edu.pl, ORCID: 0000-00028836-6044
} 
the catchment area (Ewing, Nater 2002). Furthermore, water oxygenation levels and primary production (both of which are dependent on trophic state) are responsible for shifts in redox conditions (Kajak 2001; Wesołowski et al. 2014). Finally, changes in land use and denudation rates within the catchment are also important (Foster, Dearing 1987; Borówka 1994; Mendyk et al. 2016; Okupny, Pawłowski 2021).

To compare the conditions of accumulation of individual elements, geochemical studies were often undertaken for various types of bottom sediments (Prosowicz 2008; Woszczyk et al. 2009; Gierszewski 2018), from various depositional zones within lake basins (Bojakowska, Sokołowska 1997; Szafran 2003; Aleksander-Kwarteczak, Prosowicz 2007; Małecka 2012), but less frequently considering the water-suspension-sediment relationship (Wicik, Więckowski 1991; Helios-Rybicka et al. 2005). Furthermore, the factors influencing the concentrations of selected metals in sediments were frequently determined using a selection of geochemical proxies, such as $\mathrm{Na} / \mathrm{K}$, $\mathrm{Cu} / \mathrm{Zn}, \mathrm{Fe} / \mathrm{Mn}$ and $\mathrm{Ca} / \mathrm{Mg}$ (Wojciechowski 1990; Woszczyk, Spychalski 2007; Płaza et al. 2013/2015; Pawłowski et al. 2015). The question of lake sediment enrichment in particular metals relative to the local or regional geochemical background has been addressed relatively rarely, as such an approach requires a detailed understanding of geological and hydrological conditions within the specific lake catchment (Tylmann 2005; Juśkiewicz et al. 2015). In aquatic ecosystems, the concentration of elements in sediments depends, among others, on weathering processes in the catchment, whose intensity is determined by geology and climatic conditions. In lake basins, regardless of their size, sediments undergo "focusing", which is why sedimentation rates are highest within deep areas, resulting in the highest sediment thicknesses. The potential for reconstructing human impact intensity in a region also depends on the sediment lithology, accuracy and temporal resolution achieved by geochemical studies (Słowiński et al. 2016; Kramkowski 2020; Müller et al. 2021).

Given the above, it is crucially important to study geochemistry of recent lake sediments, possibly considering all the relevant geographic features, including type of land use within the catchment. This may represent an important reference point for reconstructing sedimentation conditions with respect to their spatial and stratigraphic variability. Such interpretation should, however, be supported by numerous other analyses that are within the scope of broadly defined palaeolimnology (Tobolski 2007), hydroacoustics (Osadczuk 2017), and interpretation of archival maps, aerial photographs and satellite images (Siedlik, Borówka 2019).

Thus, the methods employed in the present paper, and the angle of our interpretation both follow a very important trend in geochemical studies on recent sediments deposited in surface water basins, which are also proxies essential for the assessment of natural environment pollution with heavy metals. Large lakes, often supplied with groundwater, may play a unique role in the geochemical cycle. The main aim of the present study was to determine the relationship between lithology and chemical composition of bottom sediments currently being accumulated in one of the deepest lakes of Pomerania. An additional aim was to assess the impact of topographic conditions and the level of human impact on the geochemistry of Lake Morzycko expressed by morphometric parameters (slopes, aspect, morphological units) and land cover examined in a wider perspective for the catchment area of the lake and the Stubia River. The present paper compares the concentrations of elements, and granulometric composition of surface sediments sampled in the nearshore zone and within deep areas of Lake Morzycko. The data collected in this study were used to plot geochemical maps that may represent an important reference for future studies regarding environmental monitoring of Myślibórz Lake District, which is increasingly susceptible to human pressure.

\section{Study area}

According to the geomorphological division of Poland (Gilewska 1968), the studied lake is located in the south-western part of Myślibórz Lake District, at its border with the Lower Odra Valley (Fig. 1). In comparison with the rest of the young-glacial relief zone, the study area is distinguished by a lower density of river network, but a higher number of small, undrained basins (Rotnicka 1987; Kostrzewski et al. 2008a).

The dominant terrain forms around Lake Morzycko are flat and undulating morainic plateaux (47\% of the surface area) and outwash plains (16\% of the area). The smallest area is occupied by river valley systems ( $0.2 \%$ of the area). Lake Morzycko occupies an area of 342.7 ha, and thus is classified as a large basin. Its maximum width is about $2.4 \mathrm{~km}$, and maximum length is about $2.9 \mathrm{~km}$. The average depth of the lake is $14.5 \mathrm{~m}$, but its maximum depth is as much as $60 \mathrm{~m}$ (Fig. 2). Lake Morzycko is 
a cryptodepression: its bottom lies $8.6 \mathrm{~m}$ below sea level (its surface is at $51.4 \mathrm{~m}$ above sea level [a.s.l.]). The studied lake is kidney-shaped, with two bays (north-western bay, 5-8 m deep, and south-western bay, 13-15 m deep) that surround the town of Moryń. The lake has a regular, 12-km-long shoreline. The lake-volume-to-surface area ratio equals 0.15 , which is one of the highest among lakes of northern Poland (Choiński 2007). The lake is a flow-through basin, as it is located within the valley of the Stubia River. The surface area of total catchment is $65.9 \mathrm{~km}^{2}$, while the direct catchment surface area is less than $10 \%$ of this value $\left(6.38 \mathrm{~km}^{2}\right)$.

The origin of the lake is not fully understood, but both morphometric features and catchment geology (tills forming a belt of end moraines representing the Chojna phase of the Pomeranian stage to the north, and sands and gravels forming

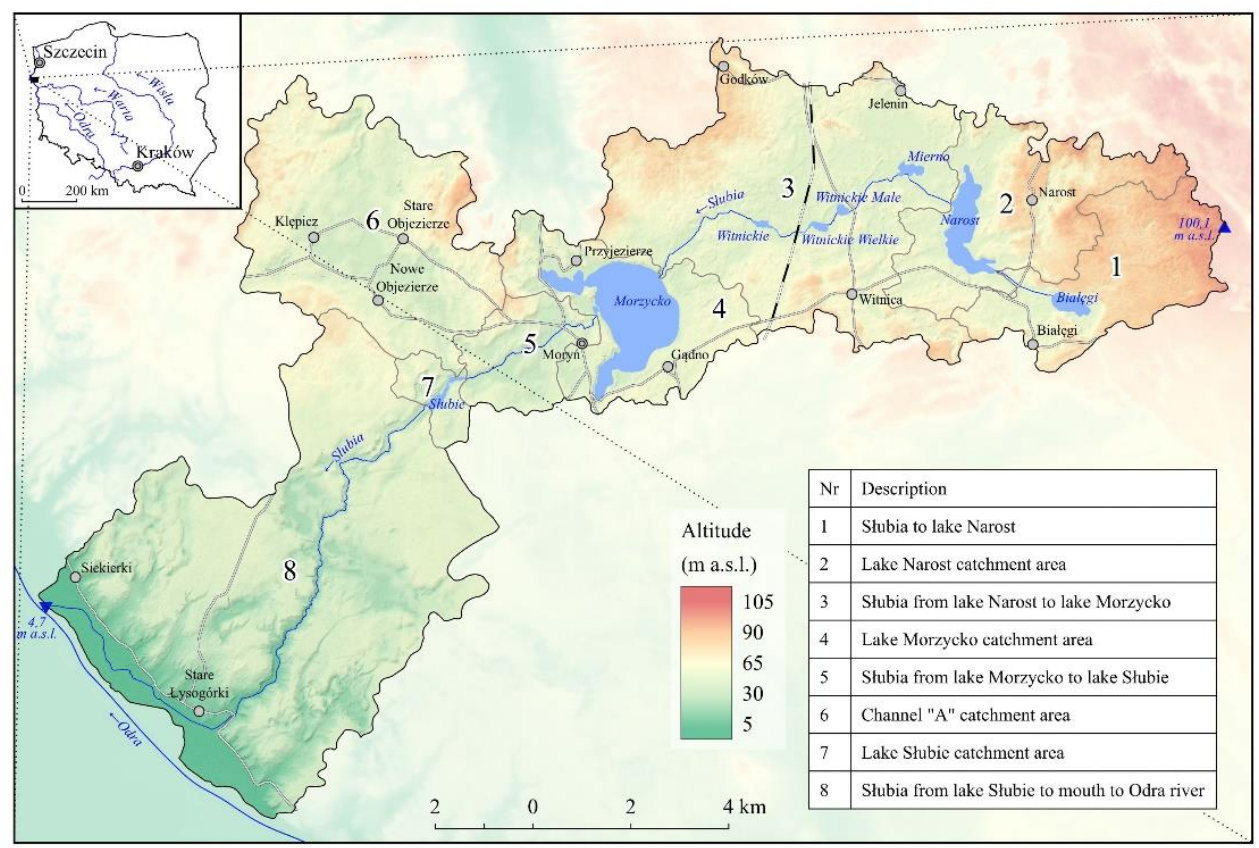

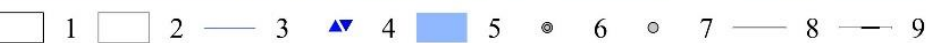

Fig. 1. Description of part of the Słubia catchment area based on Hydrographic Division of Poland

1 - border of Shubia catchment, 2 - subcatchments, 3 - rivers, 4 - extreme elevation points, 5 - lakes, 6 - cities, 7 - settlements, 8 - roads, 9 - railways

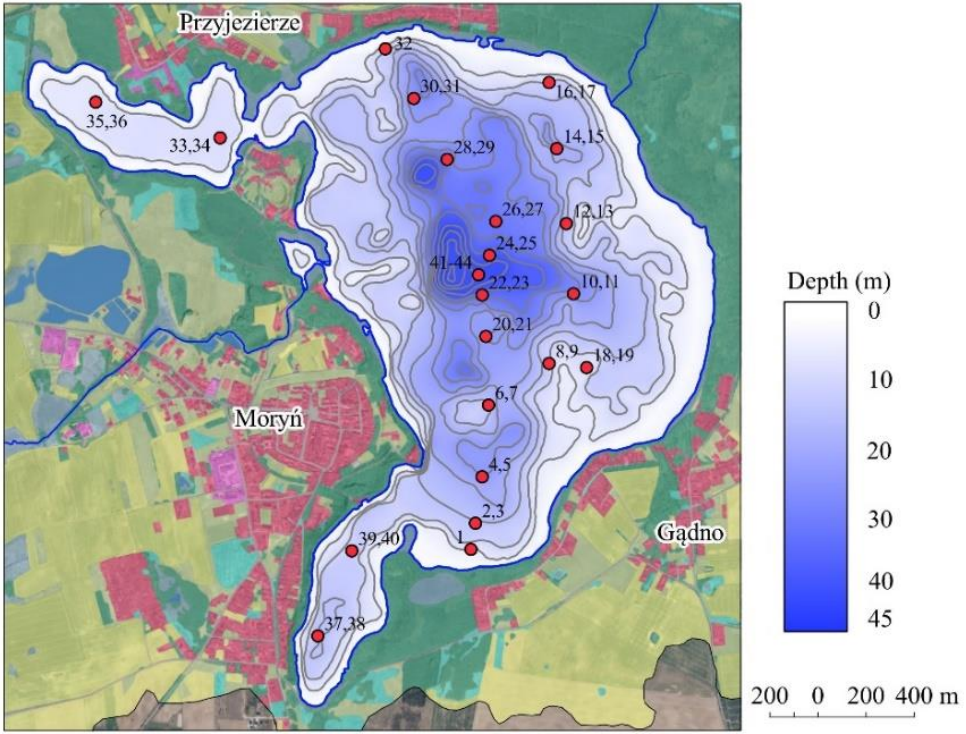

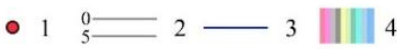

Fig. 2. Bathymetric map (after Borówka 2002) and coring sites at Lake Morzycko

1 - coring sites 2 - isobaths (every $5 \mathrm{~m}$ ), 3 - Stubia River, 4 - land cover based on orthophotomap and consistent with caption in Fig. 4D (Polish Head Office of Geodesy and Cartography 2021) 
extensive outwash plains of the Pomeranian stage to the south) may suggest evorsion as the causal mechanism for the lake basin formation (Piotrowski, Dobracki 2010). A recent study by Kotrys (2015) indicates that biogenic sedimentation was initiated during the Late Glacial (the oldest ${ }^{14} \mathrm{C}$ date is $12640 \pm 210$ conv. BP), and the first evidence of human activity in the vicinity of Lake Morzycko is represented by a distinct increase in charcoal and ruderal plant pollen frequencies dated to the late Mesolithic $\left({ }^{14} \mathrm{C} 8270 \pm 70\right.$ conv. BP).

According to the climatic regionalisation of Western Pomerania by Koźmiński et al. (2007), Lake Morzycko is located within the Myślibórz subregion, which has relatively warm and long summers (mean air temperature for July is below $18^{\circ} \mathrm{C}$ ), and mild and short winters (mean air temperature for January ranges from -0.8 to $-1.5^{\circ} \mathrm{C}$ ). The study area has the longest vegetation season in Poland (over 230 days), during which mean annual precipitation totals remain rather low (340-530 $\mathrm{mm}$ ). With respect to the development of slope processes, it is notable that diurnal rainfall exceeding $1 \mathrm{~mm}$ total is rare (from 100 to 115 days).

\section{Materials and Methods}

Three groups of methods are employed in the present work: geomorphological reconnaissance, field work and laboratory analyses. Detailed field work was preceded by an examination of morphometric properties and selected features of the geographic environment, including land-use structure for the direct catchment of Lake Morzycko, but also for the remaining partial catchments of the Stubia River. Spatial data developed by the Polish geodetic and cartographic survey were used to elaborate the cartographic part of the paper. An orthophotomap of the study area was used as source data, as well as an Airborne Laser Scanner (ALS) point cloud obtained using Light Detection And Ranging (LiDAR) technology. Based on the ALS ISOK, a high-resolution (1-m range) Digital Elevation Model (DEM) was generated. Additionally, to display elevation data for the wider area (Fig. 1), an open-source DEM from Shuttle Radar Topographic Mission (SRTM) was used. The study also used data and sketches prepared during previous field campaigns. For terrain cover analyses, the source of information was the 2020 Orthophotomap of Poland. For means of vectorisation (used Quantum GIS ver. 3.10 and GRASS ver. 2.8.4.), a division into four land cover classification groups: forests (forests and transitional woodland- shrub), non-forest areas (with an additional division into farmlands and meadows, pastures and green spaces), waters (water bodies and wetlands) and, lastly, built-up areas (buildings and roads). The bathymetry of the lake and the spatial variability of sediment chemical compositions were mapped using kriging interpolation with Surfer ver. 8.0 software.

Samples for laboratory analysis were collected during the ice-cover period, from selected sites along approximately meridional routes (from the southern to the north-eastern shore of the lake, and from the lake centre to the northern shore), and within the bays along a straight line in accordance with their orientation. Sediment samples were collected using a Nurek-1 corer (Mera Błonie Gdańsk). Eventually, a total of 44 samples were taken from 22 sites, including sediments located directly at the surface of the lake bed, and sediments from $5 \mathrm{~cm}$ below the current lake bed.

Samples were processed according to the procedure (Fig. 3) described by Borówka (1992, 2002) and Pręcikowska (2007). For geochemical analyses, the sediment samples were freeze-dried and homogenised using an agate mortar and pestle. Organic matter $(\mathrm{OM})$ content was determined by loss on ignition (LOI) at $550^{\circ} \mathrm{C}$. The ash produced by combustion was analysed for grain size and content of elements. Mineralisation in Teflon bombs was carried out in two microwave cycles: the first cycle, in concentrated nitric acid with $2 \mathrm{ml}$ of $10 \%$ hydrochloric acid, and the second cycle in hydrogen peroxide. The solution obtained was analysed for concentrations of $\mathrm{Na}, \mathrm{K}, \mathrm{Ca}, \mathrm{Mg}, \mathrm{Fe}$, $\mathrm{Mn}, \mathrm{Cu}$ and $\mathrm{Zn}$ via atomic absorption spectrometry (AAS). All analyses were conducted at the Geochemical Laboratory at the University of Szczecin.

Mineral matter was sieved through a $250-\mu \mathrm{m}$ sieve, and weighed in order to estimate the contribution of coarse $(>250 \mu \mathrm{m})$ and fine $(<250 \mu \mathrm{m})$ fractions in sediment. Eventually, a total of 39 samples (numbers: 2-5; 8-13 and 16-44) were analysed using a Mastersizer 3000 laser diffraction particle size analyser (Malvern Panalytical). Textural particle-size analysis was carried out by means of a sieve set and a Fritsch vibratory shaker only for five samples (numbers: 1, 6, 7, 14 and 15). The goal of the sieving process was to divide the mineral matter into predetermined particle-size classes. The results were interpreted using Folk and Ward (1957) indices calculated by GRADISTAT software, ver. 8.0 (Blott, Pye 2001), percentage contribution of individual modal values, SPAN parameter (a dimensionless sorting index; Foster et al. 2008). 


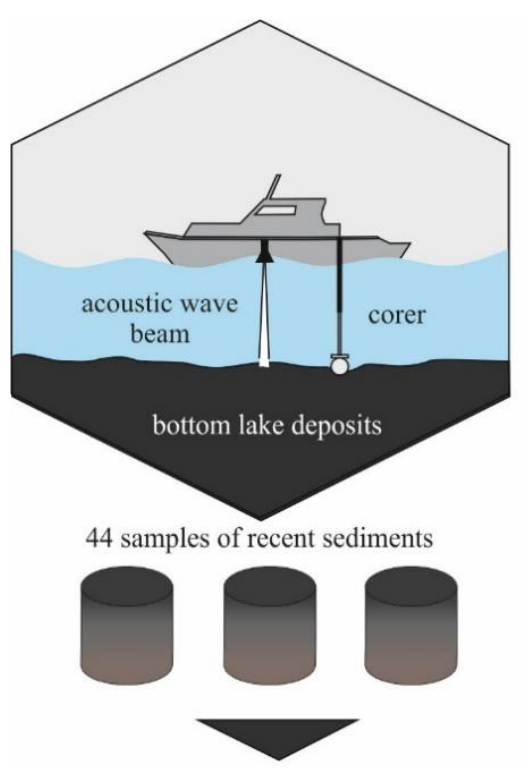

Loss on ignition analysis and division of the sediments into types and classes according to Markowski (1980) and Okruszko (1976) clasifications

Particle size of mineral matter after loss on ignition and dissolving samples in $\mathrm{KOH}$ and $\mathrm{HCl}$ (laser diffraction or sieve)

Geochemical analysis: - mineralization of ash in Teflon bombs with $\mathrm{HNO}_{3}, \mathrm{HCl}, \mathrm{H}_{2} \mathrm{O}_{2}$; - solution analysed with AAS method (concentration of: $\mathrm{Na}$, $\mathrm{K}, \mathrm{Mg}, \mathrm{Ca}, \mathrm{Fe}, \mathrm{Mn}, \mathrm{Cu}$ an $\mathrm{Zn}$ )

Samples with numbers 43 and 44 were a part of other study because they were laminated deposits

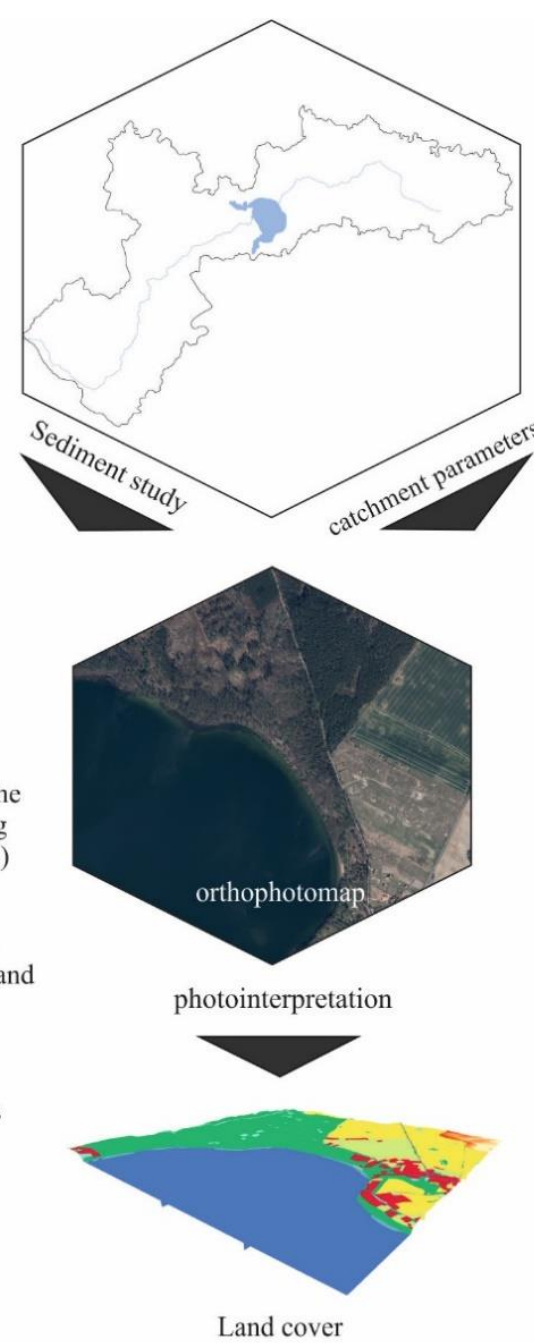

Land cover

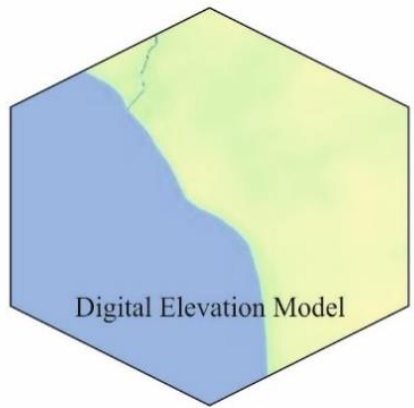

Terrain analysis

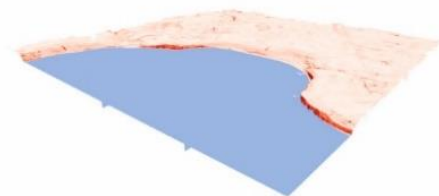

Slopes, aspect, shaded relief

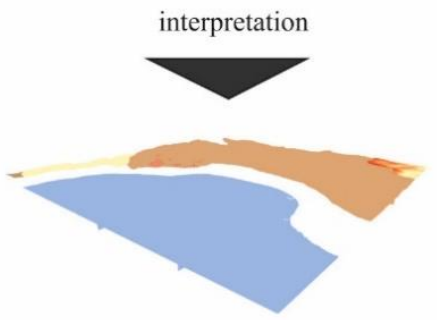

Morphological units

Fig. 3. Scheme of field work on Lake Morzycko (based partly on Borówka 2002 and Pręcikowska 2007), laboratory procedures (proposed by Borówka 1992) and GIS analysis for the catchment of the Słubia River (guidelines after Urbański, Kryla-Straszewska 2010; Jucha, Kroczak 2014)

\section{Results}

\section{Geographic catchment features of the Słubia River}

The catchment of the Stubia River is characterised by a diverse bedrock geology and morphological features (Fig. 4; Table 1). They are responsible for the shape of the contemporary slopes of the terrain. Slope angle displays a high spatial diversity, providing favourable conditions for rapid surface runoff of rainfall and meltwaters in selected parts of the partial catchment of the Słubia valley (Fig. 4A). In turn, conditions are more favourable for infiltration and evaporation in partial catchments to the north-west and northeast of Lake Morzycko. Overall, despite steep slopes, the river network density is low. River network density is highest in the east of the catchment, and equals $0.8 \mathrm{~km} / \mathrm{km}^{2}$, while in the northwest of the catchment the river network density remains below $0.4 \mathrm{~km} / \mathrm{km}^{2}$. Slopes exposed toward the north and toward the south prevail in the catchment of Lake Morzycko (Fig. 4B), which significantly alters and diversifies water relations in this area. The orientation of the slopes in the highest parts of the catchment in relation to westerly winds bringing humid air masses can clearly increase the sums of precipitation, especially between the Siekierki and Narost regions. In turn, the dominance of southern exposure over southeastern exposure in the partial catchment between Lake Narost and Lake Morzycko may be responsible for the increased intensity of evapotranspiration. 


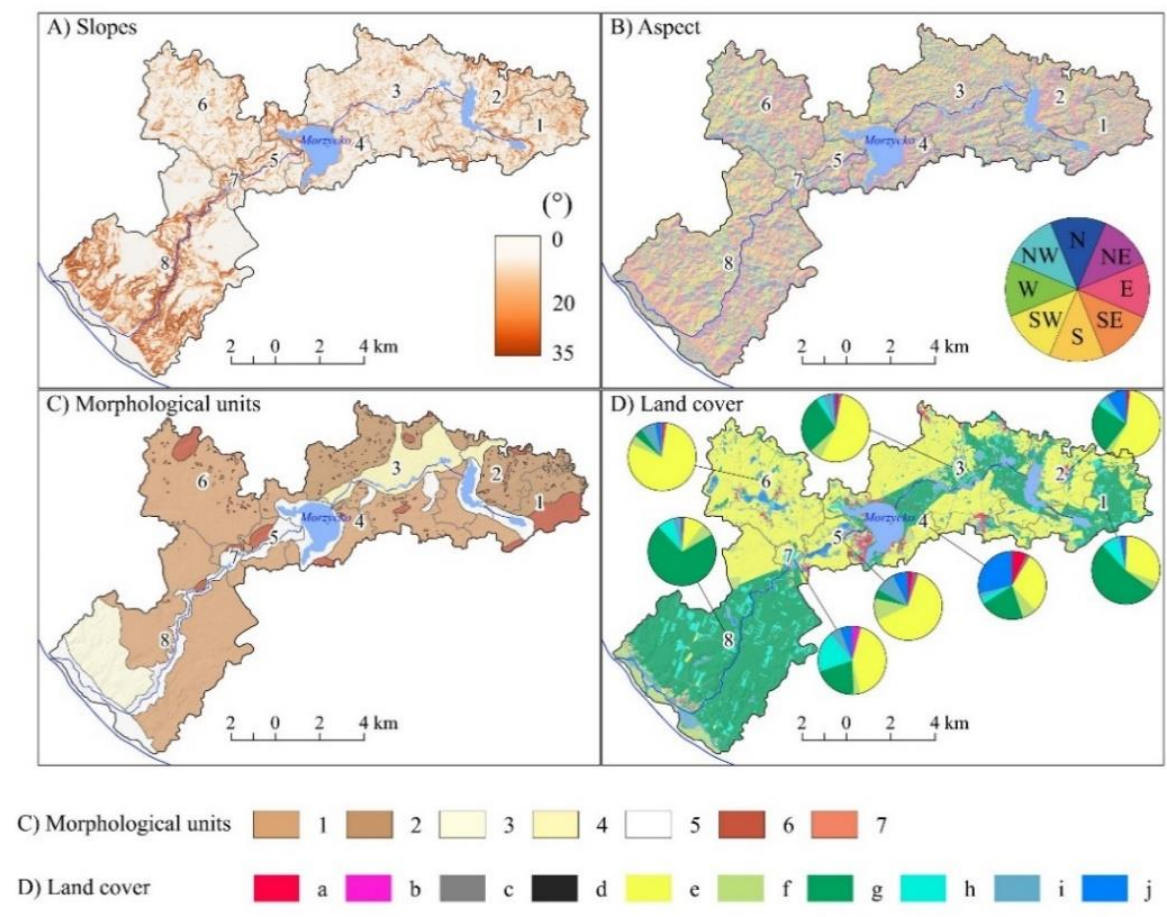

Fig. 4. Thematic maps of the Słubia catchment (based on LiDAR model, orthophotomap and Karczewski 1968)

A. Slopes

B. Slope exposure

C. Morphological units

1 - flat and undulating morainic plateau, 2 - morainic plateau with numerous kettle-holes, 3 - outwash plain of maximal subphase, 4 - outwash plain of Chojna subphase, 5 - bottom of valleys and lake channels, 6 - end moraines and other marginal forms, 7 - kettle-holes

D. Spatial variability of land cover and a percentage statement for individual subcatchments

$\mathrm{a}$ - built-up areas, b - industrial and commercial facilities, $\mathrm{c}$ - roads, $\mathrm{d}$ - railways, e - arable lands, $\mathrm{f}-$ meadows and pastures, $\mathrm{g}$ - forests, $\mathrm{h}$ - transitional woodland-shrub, $\mathrm{i}$ - wetlands, $\mathrm{j}$ - water bodies

The studied catchment is dominated by forests, which make up 54\% of the total area. The share of agricultural areas is $38 \%$. Urbanised and industrial areas represent only $0.2 \%$ of the total catchment area, but in the immediate vicinity of the lake they increase to above $1.4 \%$ (Fig. 4D). In general, the results obtained here are consistent with the morphometric classification of Southern Baltic Lake Districts (Dmowska 2008), and with spatial diversity in intensity of contemporary morphogenetic processes in the young glacial zone, considering the levels and distribution of annual rainfall sums, soil types and land cover, as compiled by Kostrzewski et al. (2008b).

\section{Chemical composition and grain-size distributions of Lake Morzycko sediments according to sedimentation zones}

The content of organic matter in research biogenic sediments was low, but varied significantly (be- tween 2 and 38\%). The average value for the central part of the lake was $18.2 \%$, while for the shore parts of the lake it was only 9\% (Fig. 5). According to the classification of lake sediments by Markowski (1980), the bottom sediments from Lake Morzycko conform mostly to clay-detritus gyttja (75\% of samples examined). Notably, Markowski's classification is based on extensive research material consisting of several hundred samples collected from various lakes of Western Pomerania. Lake Morzycko was among the 43 basins studied by Markowski (1980), who examined ten samples taken only from the deepest parts of the lake. According to the Okruszko (1976) classification, silt contents in the sediments of Lake Morzycko are very high (91\% of samples) and high (9\% of samples), because the average mineral matter content is above $63 \%$, but is usually up to $84 \%$. 
Table 1

Selected parameters of the slope and the area of slopes with different exposure in the distinguished parts of the Słubia River catchment

\begin{tabular}{|c|c|c|c|c|c|c|c|c|c|c|c|c|c|c|}
\hline \multirow[b]{2}{*}{$\begin{array}{l}\text { Description of part } \\
\text { of the Słubia catchment area }\end{array}$} & \multirow[b]{2}{*}{$\begin{array}{l}\text { Area } \\
\left(\mathrm{km}^{2}\right)\end{array}$} & \multicolumn{5}{|c|}{ Slopes $\left({ }^{\circ}\right)$} & \multicolumn{8}{|c|}{ Aspect (\% of the catchment area) } \\
\hline & & Min. & Max. & Average & Median & $\begin{array}{l}\text { Standard } \\
\text { deviation }\end{array}$ & $\mathrm{N}$ & $\mathrm{NE}$ & $\bar{E}$ & SE & $\mathrm{S}$ & SW & $\mathrm{W}$ & NW \\
\hline Słubia to Lake Narost & 10.25 & 0.01 & 18.37 & 3.15 & 2.65 & 2.36 & 12.87 & 11.95 & 10.81 & 11.40 & 13.18 & 13.49 & 13.31 & 12.95 \\
\hline Lake Narost catchment area & 12.66 & 0 & 25.54 & 3.02 & 2.59 & 2.46 & 0.68 & 11.87 & 12.50 & 13.63 & 14.49 & 15.08 & 15.77 & 15.95 \\
\hline $\begin{array}{l}\text { Shubia from Lake Narost } \\
\text { to Lake Morzycko }\end{array}$ & 28.5 & 0 & 23.52 & 2.55 & 2.16 & 2.03 & 11.73 & 11.86 & 13.10 & 14.29 & 13.47 & 11.66 & 11.77 & 12.08 \\
\hline Lake Morzycko catchment area & 11.07 & 0 & 31.1 & 2.38 & 1.53 & 3.01 & 11.25 & 12.47 & 12.28 & 12.06 & 12.61 & 13.07 & 13.13 & 13.08 \\
\hline $\begin{array}{l}\text { Słubia from Lake Morzycko } \\
\text { to Lake Słubie }\end{array}$ & 4.74 & 0 & 24.5 & 3.17 & 2.43 & 2.82 & 12.21 & 10.88 & 12.35 & 14.96 & 13.26 & 11.30 & 11.96 & 13.05 \\
\hline Channel „A” catchment area & 19.94 & 0 & 31.86 & 2.60 & 2.15 & 2.07 & 11.47 & 12.00 & 13.28 & 13.63 & 11.90 & 11.87 & 13.19 & 12.65 \\
\hline Lake Słubie catchment area & 1.84 & 0.01 & 24.15 & 3.45 & 2.31 & 3.58 & 11.47 & 12.02 & 13.70 & 15.33 & 13.04 & 10.87 & 11.50 & 12.04 \\
\hline $\begin{array}{l}\text { Słubia from Lake Słubie } \\
\text { to Siekierki }\end{array}$ & 47.37 & 0.01 & 36.65 & 3.74 & 2.20 & 4.07 & 10.65 & 10.19 & 11.55 & 13.91 & 13.86 & 13.44 & 13.52 & 12.85 \\
\hline $\begin{array}{l}\text { All area of Słubia River } \\
\text { subcatchments }\end{array}$ & 136.4 & 0 & 36.65 & 3.08 & 2.21 & 3.11 & 11.36 & 11.19 & 12.15 & 13.51 & 13.24 & 12.70 & 13.01 & 12.80 \\
\hline
\end{tabular}



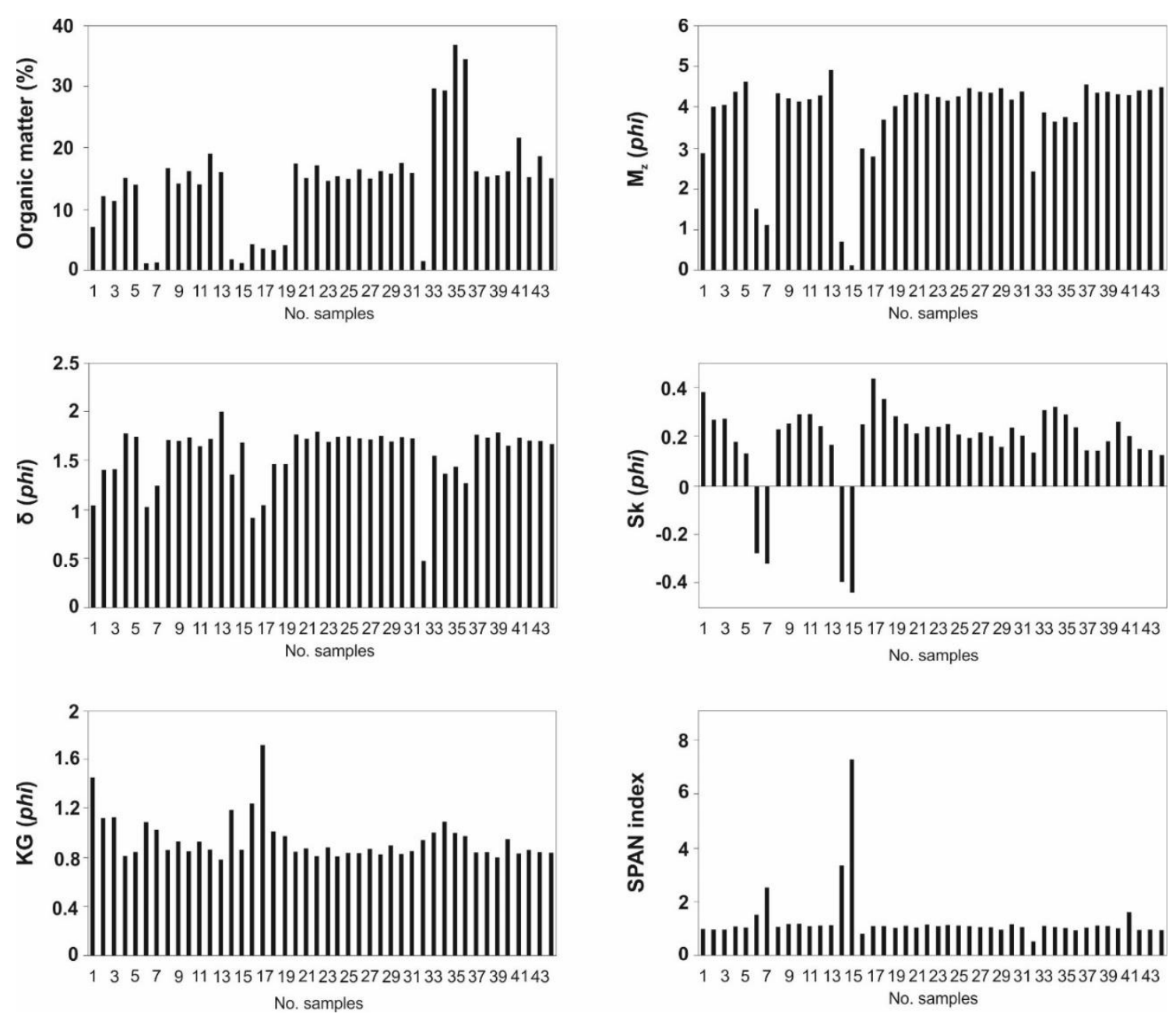

Fig. 5. Organic matter content of sediments, Folk and Ward coefficients and SPAN index for mineral fraction from recent sediments from Lake Morzycko

Despite the differences in grain-size distribution in individual types of sediments, most samples include two basic fractions, i.e., sand and silt (Fig. 6). Among those sediments that include two basic fractions are only sands, where modal values in the ranges $2.0-2.25$ and 1.5-1.74 phi characterise 40 and $60 \%$ of samples, respectively. In sandy silts, which represent slightly more than half of the samples examined here (52\%, to be exact), only one modal value is relatively strongly expressed in the sand fraction, ranging from 2.75 to 3.00 phi. In silty sands, however, a modal value of sand fraction in the range $2.5-2.75$ phi characterises $22 \%$ of samples in this population.

The relations between the distribution of individual fractions described above are reflected in the values of Folk and Ward (1957) grain-size parameters. For most samples, the values of mean grain size $\left(\mathrm{M}_{\mathrm{z}}\right)$ range from 3 to 5 phi (Fig. 5). The lowest $\mathrm{M}_{\mathrm{z}}$ values were documented in four samples taken from the southern and north-eastern

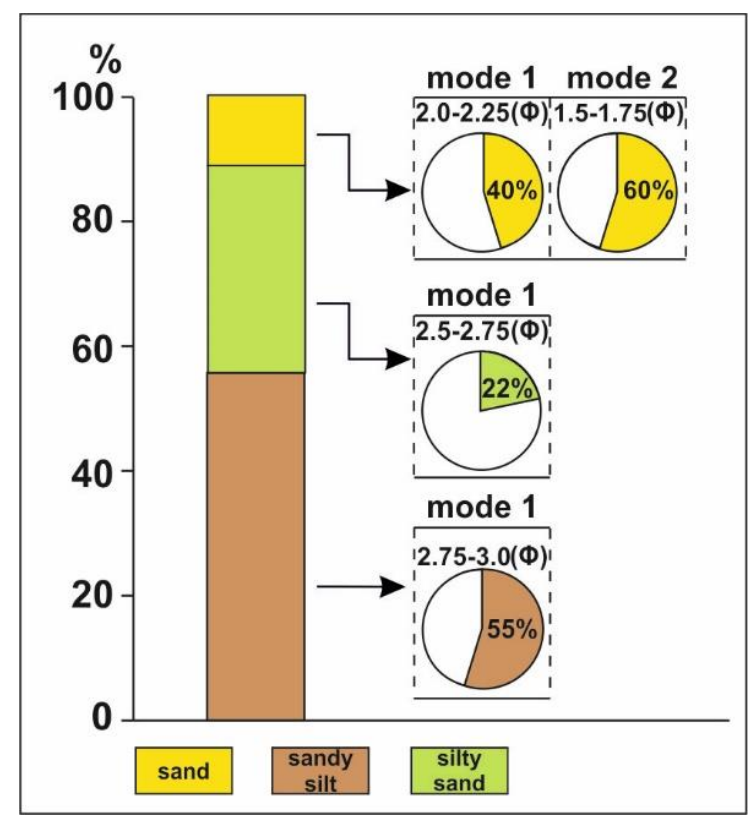

Fig. 6. Frequency (\%) of occurrence of modal fraction values (in phi) in various types of lake sediments from Lake Morzycko 
parts of the lake, in which the bottom was at a depth of about $14 \mathrm{~m}$. Standard deviation $(\delta)$ values for most samples oscillate around 1.5 phi, indicating poorer sorting of mineral material. The lowest scatter of individual grain-size classes relative to the mean value, i.e., the best sorting, was found in single samples taken in the nearshore zone of the lake, at depths below $13 \mathrm{~m}$. Negative skewness values $\left(\mathrm{S}_{\mathrm{K}}\right)$ are displayed by only 4 samples: the same samples that yielded the lowest values of the $\mathrm{M}_{\mathrm{z}}$ parameter. The remaining samples are characterised by moderate positive skewness values (ranging from 0.1 to 0.3 phi), except for samples collected from the vicinity of the southern and north-eastern shores of the lake. The least diverse are the kurtosis values $\left(\mathrm{K}_{\mathrm{G}}\right)$, where values of $\geq 1.2$ phi were assessed for only 3 samples (Fig. 5). In the case of silty sands and sandy silts, the SPAN parameter values are very similar (variation coefficient is below 10\%), and in sand group, the coefficient values vary from 0.52 to 7.26 (variation coefficient is above $85 \%$ ).

The sediments of Lake Morzycko are characterised by a high spatial diversity in concentrations of the examined geochemical components (Figs. 7, 8). Geochemical analysis indicated the narrowest range of concentrations for $\mathrm{Na}(0.02-0.36 \mathrm{mg} / \mathrm{g})$ and $\mathrm{Mn}$ $(0.2-1.2 \mathrm{mg} / \mathrm{g})$. The broadest range of concentrations was documented for Fe $(2.3-16.2 \mathrm{mg} / \mathrm{g})$. Several times higher concentrations of $\mathrm{Fe}(11-17 \mathrm{mg} / \mathrm{g}), \mathrm{Mn}$ $(0.6-0.8 \mathrm{mg} / \mathrm{g}), \mathrm{Ca}(240-260 \mathrm{mg} / \mathrm{g})$, and, to a lesser extent, $\mathrm{Mg}(3.5-4.3 \mathrm{mg} / \mathrm{g})$ were documented at the deepest sampling sites. This pattern concerns both the surface sediments, and those sampled from $5 \mathrm{~cm}$ below the lake bed. For lithophilic elements, mean concentration values formed the following series: $\mathrm{Na}<\mathrm{K}<\mathrm{Mg}$, and their mutual proportions were as follows: $0.15<0.97<2.46$.

\section{Discussion}

The morphometric analysis of Słubia River catchment confirms features typical of young glacial relief, i.e., high elevation diversity and a complex network of valleys with numerous wetlands and lakes. In the context of the immediate surrounding of Lake Morzycko, the spatial diversity of relief in individual segments of the Stubia valley is responsible also for the diversity in soil cover and plant assemblages, type of land use and intensity of human activity. These elements of the geographic environment exert control over the cycling of matter, including water, which is significant for distinguishing elementary geochemical landscapes (Wicik 1992; Rycharski, Piórkowski 2001).
Given the above determinants of morphology responsible for the chemical composition of Lake Morzycko bottom sediments, chemical and mechanical denudation processes have played an important part. The high density of undrained depressions acting as depositional collectors restricts the supply of lithophilic elements from the northern part of the Stubia River catchment. The density of undrained depressions in this part of Myślibórz Lake District exceeds 2 per km² of surface area (Fig. 4D). Peats overlain by humic clays dominate in the stratigraphy of the deposits infilling typical basins in this region (Pieńkowski 2008). Models representing the type and intensity of denudation processes based on chemical composition of sediments infilling typical western Pomeranian accumulation basins (Borówka 1992) suggest that the average quantity of material supplied to small lake basins within the Słubia catchment may have exceeded 240 $\mathrm{kg} / \mathrm{ha} /$ thousand years. The intensity of mechanical denudation processes increases downstream along the Stubia River. Alluvial fans have been deposited where the Stubia flows into Lake Morzycko and in the nearshore part of the lake, where glaciofluvial sediments are being eroded (Fig. 4C). This is corroborated by granulometric composition results, and especially so by the broad range of the SPAN index values for samples with the lowest $\mathrm{M}_{\mathrm{z}}$ values. The sand supplied to Lake Morzycko was accumulated mainly in the open water zone between the littoral and bottom zones, where the depth of the basin is below 15 metres.

Several times higher Ca concentrations (of the order $240-267 \mathrm{mg} / \mathrm{g}$ ) in bottom sediments of the southern and south-eastern parts of Lake Morzycko suggest that a more important part was played by chemical denudation in shaping the chemical composition of sediments. In the case of Lake Morzycko, the intensity of individual geochemical processes is made more spatially diverse by the catchment's diverse lithology (e.g., highly soluble rocks, mainly sands and gravels, being overlain by insoluble rocks, such as the mud and silty clay that built the proglacial lake), which manifests also in low values of average specific discharge. The compilation by Jokiel (2004) indicates that average specific discharge values in the west of Myślibórz Lake District are close to $2-3 \mathrm{dm}^{3} / \mathrm{s} / \mathrm{km}^{2}$, i.e., even five times lower than in the rest of the Polish Lowland. Previous studies on sedimentary conditions of lake sediment accumulation indicate that the variation in type and intensity of denudation processes, regardless of location within a given morphogenetic zone of Poland, was the key factor responsible for the chemical composition of biogenic sediments in the 

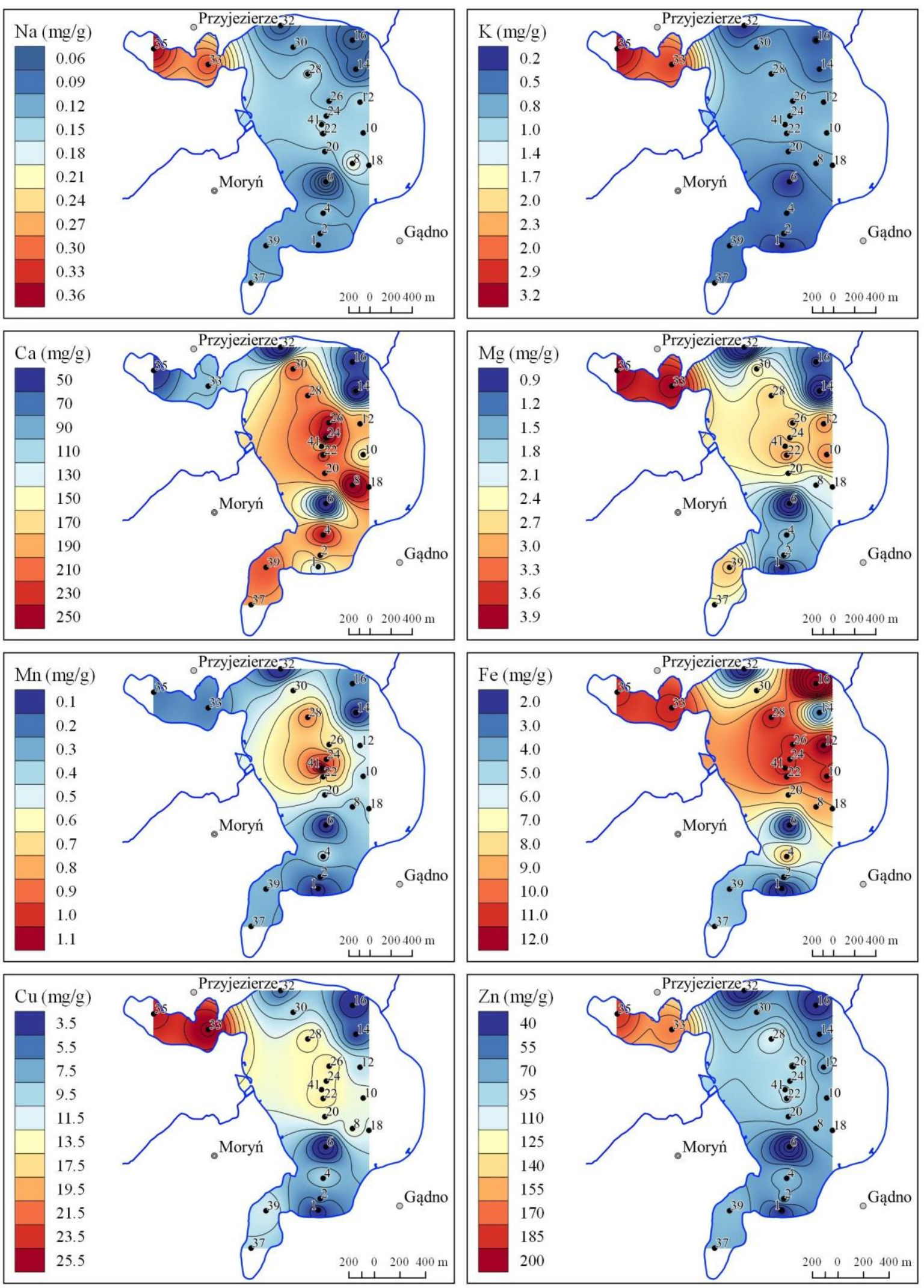

Fig. 7. Spatial distribution of researched elements

in recent Lake Morzycko sediments taken from bottom surface 

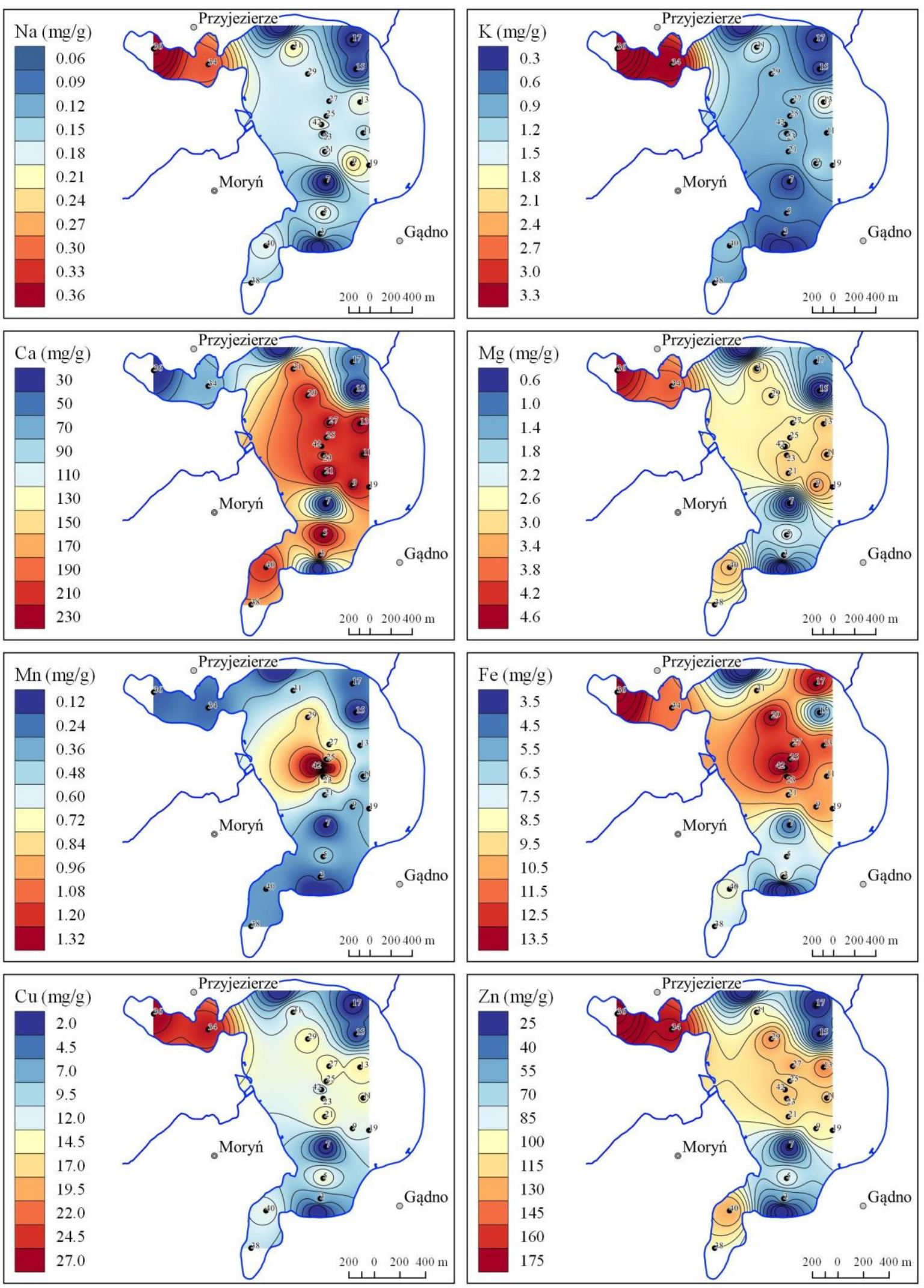

Fig. 8. Spatial distribution of researched elements in recent Lake Morzycko sediments taken from $5 \mathrm{~cm}$ below bottom surface 
Holocene (Wojciechowski 1990; Bałaga 2007; Apolinarska et al. 2012; Plak et al. 2015; Siedlik, Borówka 2019; Okupny et al. 2020).

Furthermore, bedrock geology and the resultant soil cover with dominant clay component and coarser skeletal fractions favour the development of intracover discharge, which is an important factor responsible for the concentrations of ion input in groundwaters in small catchments within the Pomeranian Lake District (Kostrzewski, Stach 1992; Szpikowska 2005). In the case of Lake Morzycko, an intensification of intracover discharge may have been associated with synchronous thaw and rainfall - a phenomenon that occurs considerably more frequently in Myślibórz Lake District than in other climatic subregions of Western Pomerania (Koźmiński et al. 2007). Considering the mutual relationship between $\mathrm{Na}$ and $\mathrm{K}$ concentrations in the bottom sediments of Lake Morzycko, there was a distinct prevalence of passive supply of allochthonous mineral matter $(\mathrm{Na} / \mathrm{K}$ index values below 0.2 in middle and north of the lake bed). Importantly, the role of chemical denudation in the case of sediments resting directly on the lake bed in the north-eastern part of the lake $(\mathrm{Na} / \mathrm{K}$ index values between 0.5 and 0.8 ) is more important compared to the sediments sampled from greater depths. This situation indicates selective Na concentrations resulting from leaching and has been recorded in other lakes in the north-western part of the Polish Lowlands (Borówka 1992). This may be due to an increase in surplus water entering the underground phase of the cycle, and its drainage via the lake. For catchments in the young glacial zone, an important part in supplying aquifers is ascribed to endorheic areas, and numerous undrained depressions, often those at watershed positions (Gocłowski 1975/76; Kostrzewski et al. 2008b; Pietruszyński et al. 2015). Further, the higher $\mathrm{Na}$ concentrations may result from a diminished supply of potassium ions to the lake waters. Previous research by Mazurek (1999) based on the Kłuda catchment in Western Pomerania indicates that potassium concentrations in aquatic environments are highly variable dependent on soil humidity, the potential for mobilising metals from soil colloids, and conditions of biological cycling functioning (e.g., displacement of potassium ions from leaves and decaying plant matter in autumn and winter). In addition to the factors discussed above, factors shaping water erosion also include locally varying weather conditions. A monitoring of the catchment of Potok Jeleni, located just $6 \mathrm{~km}$ to the northeast of Lake Morzycko and adjacent to the Stubia catchment, indicated that the moderate to medium degree of water erosion intensity is associated predominantly with waters from the early spring thaw (Koćmit et al. 2006).

Further factors that may significantly shape the chemical composition of inflowing waters and sediments deposited at the bottom of Lake Morzycko are locally diverse retention conditions and the duration of water contact with the substrate. In the upper course of the Stubia valley, slightly lower terrain slopes gradients at the morainic plateau, in conjunction with poor substrate permeability, mean that surface water retention and evapotranspiration play a major part. This is especially important given that Lake Morzycko represents the second-last unit in a system of lake basins connected by the Stubia River. All the lakes in the Stubia catchment form a cascade of flow-through lakes, in which Lake Białęgi (61 m a.s.l.) is the first and highest step, from which the Stubia originates. Water flows through a narrow bed of about $800 \mathrm{~m}$ long to the next step of the cascade, Lake Narost (58.1 $\mathrm{m}$ a.s.1.), and continues through a peat-infilled depression to four subsequent lakes (Mierno, Witnickie Małe, Witnickie Wielkie, Witnickie). The surface area of each of these lakes ranges from 6 to 8 ha. These lakes receive allochthonous material and create a buffer system which is crucial for the entire valley, as the sum of their partial catchments represents as much as $42 \%$ of the entire Stubia catchment. Furthermore, the map of dispersed downwash threat by Józefaciuk and Józefaciuk (1992) indicates that soil cover characterised by the highest degree of potential erosion occurs only within partial catchments of the upper course of the Stubia valley. Over the remaining 1.2-km-long course, the Stubia flows to Lake Morzycko through a broad and highly marshy valley whose slope does not exceed 1.2\%o. Over its outlet stretch, about $14.6 \mathrm{~km}$ long, the Shubia flows to the Odra River through a slightly deeper, narrow depression representing a gap with a slope of about $3.9 \%$. The autumn discharge is merely $0.39 \mathrm{dm}^{3} / \mathrm{s}$, but note that the Stubia has no tributaries along its entire length. The results of the present study may indicate that waters with highly contrasting chemical features mix within the basin of Lake Morzycko, which leads to the accumulation of mineral-organic sediments with varying concentrations of mineral components on the lake bed.

Lake Morzycko sediments are characterised by a notably higher contribution of both lithophilic elements ( $\mathrm{Na}, \mathrm{K}$ and $\mathrm{Mg}$ ), and $\mathrm{Ca}$ and $\mathrm{Zn}$ concentrations in sediments, as compared to sediments from other water basins of northern Poland (cf. Bojakowska, Sokołowska 1996; Borówka 2001; 
Trojanowski, Antonowicz 2005; Woszczyk et al. 2009; Podlasińska, Szydłowski 2017; Korzeniowski et al.2020). This is caused by intense leaching of mineral components and their transport by groundwaters over relatively flat surfaces characterised by favourable infiltration conditions. Such conditions occur mainly to the north-west and south of Lake Morzycko, where despite almost $30 \%$ lower potential hydrologically active zone relative to the upper course of Stubia catchment (Mądry, Połaniecka 2000), fluvioglacial sands and gravels prevail, with local occurrences of tills superjacent to sands and gravels with moderate and high permeability. The conditions of migration, transport and bonding of research metals depends on regional geochemical background, depth of Lake Morzycko, variable erosion on the individual subcatchments and the redox conditions. This is supported by the maximum values of $\mathrm{Fe} / \mathrm{Mn}$ index, whose spatial distribution indicates a relationship with the location of wetlands in the north-western part of Lake Morzycko.

According to the classification of contamination by trace elements proposed by Bojakowska (2001), the studied sediments of Lake Morzycko are classified as $1^{\text {st }}$ - and $2^{\text {nd }}$-class sediments. The first group includes sediments considered unpolluted, while the second group are weakly polluted sediments with sporadic impact on biota. With respect to $\mathrm{Cu}$ concentrations, only four samples were included in the second purity class, i.e., sediments sampled in the north-western bay of Lake Morzycko, which are directly prone to anthropogenic pollution by the village of Przyjezierze. These same samples yielded elevated concentrations of $\mathrm{Zn}$, close to or slightly exceeding the geochemical background. A similar observation has been made for other aquatic sediments in north-western Poland, especially for samples collected from Odra River valley between Kostrzyn and Szczecin (Bojakowska, Sokołowska 1998), Lake Wonieść in Poznań Lake District (Hildebrandt-Radke et al. 2011), and Lake Gostyń in Myślibórz Lake District (Korzeniowski et al. 2020). Higher concentrations have been found only for $\mathrm{Ca}$ and $\mathrm{Mg}$ in bottom sediments of Lake Racze in Pyrzyce Lowland, where a larger proportion of land is being farmed (Bloom 2015). A study by Burczyk et al. (2015) indicates that in agricultural catchments of Western Pomerania, farming activity does not display a direct impact on seasonal changes in Ca-to- $\mathrm{Mg}$ ratio in ground waters supplied to water basins. A more important role in $\mathrm{Ca}$ and $\mathrm{Mg}$ cycling should therefore be ascribed to the values of the local geochemical background of the bedrock. The amount of these elements in the recent sediments of Lake Morzycko is mainly of natural origin. They come from dissolution of the bedrock by acid rainwater and alkaline groundwater. Therefore, these are the denudation components of all the displaced dissolved material, which in northern Poland depend on, among other things, season or water hardness (Kostrzewski, Zwoliński 1992).

\section{Conclusion}

The present study, conducted on Lake Morzycko and accompanied by a detailed reconnaissance of factors influencing contemporary potential morphogenetic processes in the catchment of the Stubia River confirmed the key role of differences in functioning of a morainic plateau and outwash plain denudational system on the chemical composition and granulometry of bottom sediments. Most of the studied samples (75\%) conform to the clay-detritus gyttja group in the classification of lake sediments compiled for Western Pomerania.

A comparison of the results of geochemical studies on lake sediments indicated that the concentrations of most of the elements examined is higher in the samples taken from deep areas than in sediments sampled in the nearshore zone. The relationship between the examined metals and organic matter or fine mineral fraction confirms that, in stratigraphic interpretations, it is imperative to include variability in chemical composition of biogenic sediments such processes as bioaccumulation and intensity of weathering processes, as well as passive supply of lithogeochemical components to the basin.

The spatial relationship between lithophilic elements concentrations, regardless of the sampling depth, is not always strong in individual parts of Lake Morzycko. This is due to thew various sources of supply and transport of these components to the lake, including leaching of catchment bedrock by ground waters, but also penetration of the shallow substratum by rainfall or meltwaters associated with the Słubia River.

In studies on lake bottom sediments characterised by heterogeneous chemical composition statistical indices may provide necessary information for reconstructing sedimentary conditions. In the case of Lake Morzycko sediments, such a part was played by $\mathrm{Na} / \mathrm{K}$ and SPAN indices. Changes in research elements were due to varying biological productivity, intensity of weathering of postglacial material making up the catchment, and potential 
for migration of metals to the lake with surface or underground runoff.

Assessment of the contamination state of Lake Morzycko sediments using the local geochemical background showed significant differences in pollution of the shallow parts of the lake near the tourist districts of Moryń. At the same time, the central and southern parts of the lake, despite higher surface water supply and widespread farming, show a lower degree of contamination.

\section{References}

Aleksander-Kwarteczak U., Prosowicz D. 2007. Distribution of $\mathrm{Cd}$ and $\mathrm{Pb}$ in the lake sediments cores from the Hańczańska Bay (Wigry Lake, NE Poland). Limnological Review 7,4: 215-219.

Apolinarska K., Woszczyk M., Obremska M. 2012. Late Weichselian and Holocene palaeoenvironmental changes in northern based on the Lake Skrzynka record. Boreas 41: 292-307.

Bałaga K. 2007. Changes in the natural environment recorded in the sediments of the Karaśne lakemire complex (Lublin Polesie, E Poland). Geochronometria 29: 1-21.

Bloom K. 2015. Wpływ czynników naturalnych i gospodarki pradziejowej na sukcesję roślinności w rejonie Jeziora Raczego na Ziemi Pyrzyckiej w holocenie. Studium paleoekologiczne. PhD Thesis. University of Gdańsk, Gdańsk.

Blott S.J., Pye K. 2001. A grain size distribution and statistics for the analysis of unconsolidated sediments. Earth Surface Processes Landforms 1248: 1237-1248.

Bojakowska I. 2001. Kryteria oceny zanieczyszczenia osadów wodnych. Przegląd Geologiczny 49,3: 213-218.

Bojakowska I., Sokołowska G. 1996. Metale ciężkie w osadach jezior Pojezierza Kaszubskiego. Przegląd Geologiczny 44,9: 920-923.

Bojakowska I., Sokołowska G. 1997. Akumulacja pierwiastków śladowych w osadach jeziornych w zależności od strefy sedymentacji. Przegląd Geologiczny 45,5: 505-508.

Bojakowska I., Sokołowska G. 1998. Geochemiczne klasy czystości osadów wodnych. Przegląd Geologiczny 46,1: 49-54.

Borówka R.K. 1992. Przebieg i rozmiary denudacji w obrębie śródwysoczyznowych basenów sedymentacyjnych podczas późnego vistulianu i holocenu. Wyd. Nauk. UAM, seria Geografia, 54.

Borówka R.K. 1994. Naturalne i antropogeniczne uwarunkowania zmian denudacji podczas holocenu. Roczniki Akademii Rolniczej w Poznaniu 266, 14: 27-37.
Borówka R.K. 2001. Stratygraficzna zmienność składu chemicznego osadów wypełniających Zalew Szczeciński i Jezioro Dąbie. Geologia i geomorfologia 4: 9-24.

Borówka R.K. 2002. Środowisko geograficzne. In: R.K. Borówka, S. Friedrich, T. Heese, J. Jasnowska, R. Kochanowska, M. Opęchowski (eds) Przyroda Pomorza Zachodniego. Wyd. Oficyna In Plus, Szczecin.

Borówka R.K. 2007. Geochemiczne badania osadów jeziornych strefy umiarkowanej. Studia Limnologica et Telmatologica 1,1: 33-42.

Burczyk P., Rawicki K., Gałczyńska M., Brysiewicz A., Marciniak A. 2015. Ocena stężenia magnezu i wapnia w wodach gruntowych na terenach rolniczych Pomorza Zachodniego. Woda-Środowisko-Obszary Wiejskie 15,3: 15-23.

Choiński A. 2007. Limnologia fizyczna Polski. Wyd. Nauk. UAM Poznań.

Dmowska A. 2008. Klasyfikacja Pojezierzy Południowobałtyckich i Pojezierzy Wschodniobałtyckich w oparciu o kryterium morfometryczne. Landform Analysis 9: 345-347.

Ewing A.H., Nater A.E. 2002. Holocene soil development on till and outwash inferred from lake-sediments geochemistry in Michigan and Wisconsin. Quaternary Research 57,2: 234-243.

Florek W., Majewski M. 2008. Morfo- i osadotwórcze skutki zmian poziomu jeziora Jasień w późnym vistulianie i holocenie. Landform Analysis 7: 3542.

Folk R., Ward W. 1957. Brazor River bar: a study in the significance of grain size parameters. Journal of Sedimentary Petrology 27,1: 3-26.

Foster I.D.L., Dearing J.A. 1987. Lake catchments and environmental chemistry: a comparative study of contemporary and historical catchment processes in Midland England. GeoJournal 14,3: 285-297.

Foster I.D.L., Oldfield F., Floer R.J., Keatings K. 2008. Mineral magnetic signatures in a long core from Lake Quarun, middle Egypt. Journal of Paleolimnology 40: 838-849.

Gałuszka A. 2006. Metody określania tła geochemicznego w badaniach środowiska przyrodniczego. Regionalne Studia Ekologiczno-Krajobrazowe. Problemy Ekologii Krajobrazu 16: 507-517.

Gierszewski P. 2018. Hydromorfologiczne uwarunkowania funkcjonowania geoekosystemu Zbiornika Włocławskiego. Prace Geograficzne IGiPZ PAN 268.

Gilewska S. 1986. Podział Polski na jednostki geomorfologiczne. Przeglad Geograficzny 58: 15-40.

Gocłowski A. 1975/76. Morfologiczny endoreizm na dziale wodnym między Odrą a Wisłą. Annales Universitatis Mariae Curie-Skłodowska, sectio B 30/31: 165-188. 
Helios-Rybicka E., Kuźniakowska M., Gruszecka A. 2005. Zanieczyszczenie chromem Jeziora Rożnowskiego. Inżynieria Środowiska 10,2: 161174.

Hildebrandt-Radke I., Spychalski W., Lutyńska M. 2011. Regionalna wymowa procesów antropogenizacji regionu środkowej Obry na postawie badań osadów jeziora Wonieść. Landform Analysis 16: 92-97.

Jokiel P. 2004. Zasoby wodne środkowej Polski na progu XX wieku. Wyd. UŁ, Łódź.

Józefaciuk A., Józefaciuk C. 1992. Struktura zagrożenia erozją wodną fizjograficznych krain Polski. $\mathrm{Pa}$ miętniki Puławskie, Suplement 101: 23-49.

Jucha W., Kroczak R. 2014. Porównanie danych o użytkowaniu terenu z program CORINE Land Cover z danymi uzyskanymi z ortofotomap. In: E. Kaczmarska, P. Raźniak (eds) Społeczno-ekonomiczne i przestrzenne przemiany struktur regionalnych, vol 2. Kraków, Oficyna Wydawnicza AFM: 123-136.

Juśkiewicz W., Marszelewski W., Tylmann W. 2015. Differentiation of the concentration of heavy metals and persistent organic pollutants in lake sediments depending on the catchment management (Lake Gopło case study). Bulletin of Geography, Physical Geography Series 8: 71-80.

Kajak Z. 2001. Hydrobiologia - limnologia. Ekosystemy wód śródlądowych. Wyd. Nauk. PWN, Warszawa.

Karczewski A. 1968. Geomorphology of the Myślibórz Lakeland and Szczecin Lowland. Numerical Geomorphological Map 1: 200 000. Wyd. Adam Mickiewicz University in Poznań.

Kittel P., Mazurkevich A., Wieckowska-Lüth M., Pawłowski D., Dolbunova E., Płóciennik M., Gauthier E., Krąpiec M., Maigrot Y., Danger M., Mroczkowska A., Okupny D., Szmańda J., Thiebaut E., Słowiński M. 2021. On the border between land and water: The environmental conditions of the Neolithic occupation from 4.3 until 1.6 BC at Serteya, Western Russia. Geoarchaeology. An International Journal 36,2: 173-202.

Koćmit A., Podlasiński M., Roy M., Tomaszewicz T., Chudecka J. 2006. Water erosion in the catchment basin of the Jeleni Brook. Journal of Water and Land Development 10: 121-131.

Kostrzewski A., Stach A. 1992. Uwarunkowania zmienności czasowej koncentracji substancji rozpuszczonych w mikrozlewniach (zlewnia górnej Parsęty, Pomorze Zachodnie). In: A. Kostrzewski, M. Pulina (eds) Metody hydrochemiczne w geomorfologii dynamicznej. Wybrane problemy. Prace Naukowe Uniwersytetu Śląskiego, Katowice, 1254: 143-167.

Kostrzewski A., Zwoliński Z. 1992. Denudacja chemiczna w zlewniach młodoglacjalnych: zlewnia górnej Parsęty, rok hydrologiczny 1987. In: A. Kostrzewski, M. Pulina (eds) Metody hydrochemiczne $w$ geomorfologii dynamicznej. Wybrane problemy. Prace Naukowe Uniwersytetu Śląskiego 1254: 106-126.

Kostrzewski A., Zwoliński Z., Andrzejewski L., Florek W., Mazurek M., Niewiarowski W., Podgórski Z., Rachlewicz G., Smolska E., Stach A., Szmańda J., Szpikowski J. 2008a. Współczesna ewolucja rzeźby młodoglacjalnej Niżu Polskiego. In: L. Starkel, A. Kostrzewski, A. Kotarba, K. Krzemień (eds) Współczesne przemiany rzeźby Polski. IGiGP UJ, Kraków: 271-326.

Kostrzewski A., Zwoliński Z., Andrzejewski L., Florek W., Mazurek M., Niewiarowski W., Podgórski Z., Rachlewicz G., Smolska E., Stach A., Szmańda J., Szpikowski J. 2008b. Współczesny morfosystem strefy młodoglacjalnej. Landform Analysis 7: 7-11.

Korzeniowski A., Okupny D., Michczyński A., Sławińska J., Borówka R.K. 2020. Lithology and geochemistry of the Late Glacial and Holocene sediments from Gostyń Lake (Western Pomerania, Myślibórz Lakeland). Acta Geographica Lodziensia 110: 149-168.

Kotrys B. 2015. Zapis zmian środowiska i klimatu od późnego glacjału do holocenu w profilu osadów dennych Jeziora Morzycko na podstawie analiz palinologicznych. Materiały konferencyjne 2 Konferencji Naukowej „Paleoklimat. Zmiany klimatyczne w przeszłości geologicznej” 24-25 listopada, Państwowy Instytut Geologiczny, Warszawa: 95.

Koźmiński C., Michalska B., Czarnecka M. 2007. Klimat województwa zachodniopomorskiego. Wyd. P.P.H. ZAPOL Dmochowski, Sobczyk, Szczecin.

Kramkowski M. 2020. Paleośrodowiskowe znaczenie zmian tempa i charakteru sedymentacji osadów jeziora Jelonek w Borach Tucholskich. Przeglad Geograficzny 92,3: 409-422.

Małecka K. 2012. Geochemiczna zmienność pierwiastków ziem rzadkich i metali ciężkich w osadach profundalu i litoralu wybranych jezior Polski. Biuletyn Państwowego Instytutu Geologicznego 450: 63-74.

Markowski S. 1980. Struktura i właściwości podtorfowych osadów jeziornych rozprzestrzenionych na Pomorzu Zachodnim jako podstawa ich rozpoznawania i klasyfikacji. In: Kreda jeziorna i gytia. Vol. 2, Poznańskie Towarzystwo Przyjaciół Nauk i Ziemi, Gorzów-Zielona Góra: 44-55.

Mazurek M. 1999. Dynamika transportu substancji rozpuszczonych w zlewni młodoglacjalnej (zlewnia Kłudy, Pomorze Zachodnie). Przeglą Geograficzny 71,3: 247-267.

Mądry J., Połaniecka B. 2000. Mapa hydrogeologiczna Polski w skali 1:50 000, arkusz Chojna. Państwowy Instytut Geologiczny, Warszawa.

Mendyk Ł., Markiewicz M., Bednarek R., Świtoniak M., Gamrat W.W., Krześlak I., Sykuła M., Gersztyn L., Kupniewska A. 2016. Environmental changes of a shallow kettle lake catchment in 
young glacial landscape (Sumowskie Lake catchment), North-Central Poland. Quaternary International 418: 116-131.

Müller D., Tjallingii R., Płóciennik M., Luoto T.P., Kotrys B., Plessen B., Ramisch A., Schwab M.J., Błaszkiewicz M., Słowiński M., Brauer A. 2021. New insigths into lake responses to rapid climate change: the Younger Dryas in Lake Gościąż, central Poland. Boreas 50,2: 535-555.

Okupny D., Pawłowski D. 2021. Elemental composition of biogenic sediments reveals palaeoclimatic changes during the Late Weichselian in a Central European river valley: A statistical approach. Catena 200: 105188.

Okupny D., Borówka R.K., Cedro B., Sławińska J., Tomkowiak J., Michczyński A., Kozłowska D., Kowalski K., Siedlik K. 2020. Geochemistry of a sedimentary section at the Wąwelnica archaeological site, Szczecin Hills (Western Pomerania). Acta Geographica Lodziensia 110: 169186.

Okruszko H. 1976. Zasady rozpoznawania i podziału gleb hydrogenicznych z punktu widzenia potrzeb melioracji. Biblioteczka Wiadomości IMUZ 52: 7-53.

Osadczuk A. 2017. Badania osadów dennych akwenów śródlądowych z zastosowaniem metod hydroakustycznych. Rozprawy i Studia Uniwersytetu Szczecińskiego 964.

Pawłowski D., Milecka K., Kittel P., Woszczyk M., Spychalski W. 2015. Palaeoecological record of natural changes and human impact in a small river valley in Central Poland. Quaternary International 370: 12-28.

Pieńkowski P. 2008. Distribution of small, water - filled depressions as a component of the analysis of icesheet retreat dynamics in young glacial areas. Landform Analysis 6: 41-46.

Pietruszyński Ł., Cieśliński R., Woźniak E., Jokiel J. 2015. Transport substancji biogenicznych w zlewni młodoglacjalnej na tle sezonowych zmian struktury hydrograficznej (na przykładzie zlewni Borucinki). Woda-Środowisko-Obszary Wiejskie 15,3: 75-88.

Piotrowski A., Dobracki R. 2010. Problemy budowy geologicznej czwartorzędu Pojezierza Myśliborskiego - georóżnorodność, krajobraz naturalny i historyczny. In: P. Karnowski, A. Piotrowski (eds) Budowa geologiczna, geologia naftowa, wody geotermalne i ochrona środowiska Bloku Gorzowa - Pojezierza Myśliborskiego. Materiały konferencyjne LXXX Zjazdu Naukowego Polskiego Towarzystwa Geologicznego, Szczecin 11-14 września 2010 r. Wyd. PIG-PIB, Szczecin: 67-74.

Plak A., Chodorowski J., Pidek I.A., Dobrowolski R. 2015. Selected geochemical criteria in mire profiles of Poręby Wojsławskie (Sandomierz Basin, Poland SE). Polish Journal of Soil Science 48,1: 91-99.
Płaza D., Forysiak J., Borówka R.K., Okupny D., Marosik P., Obremska M., Michczyńska D.J. 2013/2015. Aktywność osadnicza grup mezolitycznych na obszarze wydm w Aleksandrowie i jej zapis w osadach przyległego torfowiska Rąbień. Prace i Materiały Muzeum Archeologicznego i Etnograficznego w Lodzi, Seria Archeologiczna 46: 229-250.

Podlasińska J., Szydłowski K. 2017. Charakterystyka stężeń wybranych metali ciężkich w osadach dennych Jeziora Byszyno oraz określenie ich potencjalnego zagrożenia środowiskowego. WodaŚrodowisko-Obszary Wiejskie 17,3: 85-99.

Pręcikowska D.A. 2007. Właściwości fizyczne, skład chemiczny i subfosylna malakofauna osadów współczesnych Jeziora Morzycko. Maszynopis pracy magisterskiej. Uniwersytet Szczeciński.

Prosowicz D. 2008. Metale w osadach dennych Jeziora Wigry. Geologia 34,1: 85-108.

Rotnicka J. 1987. Przestrzenna koncentracja jezior w województwie gorzowskim. Badania Fizjograficzne nad Polska Zachodnia 37: 89-95.

Rutkowski J. 2007. Osady jezior w Polsce. Charakterystyka i stan rozpoznania, metodyka badan, propozycje. Studia Limnologica et Telmatologica 1,1: 17-24.

Rycharski M., Piórkowski H. 2001. Wpływ warunków geologicznych i rzeźby terenu na zróżnicowanie siedlisk hydrogenicznych w wybranych mezoregionach strefy staroglacjalnej. Woda-Środowisko-Obszary Wiejskie 1,3: 23-36.

Siedlik K., Borówka R.K. 2019. Zmiany poziomu wody jezior doliny środkowej Płoni w czasach historycznych ze szczególnym uwzględnieniem jeziora Miedwie. Rozprawy i Studia Uniwersytetu Szczecińskiego 1086.

Słowiński M., Marcisz K., Płóciennik M., Obremska M., Pawłowski D., Okupny D., Słowińska S., Borówka R.K., Kittel P., Forysiak J., Michczyńska D.J., Lamentowicz M. 2016. Drought as stress driver of ecological changes in peatland A palaeoecological study of peatland development between $3500 \mathrm{BCE}$ and $200 \mathrm{BCE}$ in central Poland. Palaeogeography, Palaeoclimatology, Palaeoecology 461: 272-291.

Szafran K. 2003. Metale ciężkie w osadach dennych trzech płytkich jezior Łęczyńsko-Włodawskich. Acta Agrophysica 1,2: 329-337.

Szpikowska G. 2005. Jakość wód infiltrujących jako wyznacznik intensywności ługowania gleb (zlewnia Chwalimskiego Potoku, górna Parsęta). In: A. Kostrzewski, R. Kolander (eds) Zintegrowany Monitoring Środowiska Przyrodniczego. Funkcjonowanie i monitoring geoekosystemów Polski warunkach zmian klimatu i różnokierunkowej antropopresji. Biblioteka Monitoringu Środowiska, Poznań: 167-181. 
Szwarczewski P., Smolska E. 2013. Cechy geochemiczne osadów stokowych i fluwialnych na północno-zachodnim Mazowszu. Prace i Studia Geograficzne 51: 105-123.

Tobolski K. 2004. Kryterium geologiczne w badaniach zbiorników akumulacji biogenicznej. Regionalny Monitoring Środowiska Przyrodniczego 5: 119-126.

Tobolski K. 2007. Paleolimnologia widziana przez pryzmat sfery biotycznej. Studia Limnologica et Telmatologica 1,1: 43-50.

Trojanowski J., Antonowicz J. 2005. Właściwości chemiczne osadów dennych jeziora Dołgie Wielkie. Stupskie Prace Biologiczne 2: 123-133.

Tylmann W. 2005. Lithological and geochemical record of anthropogenic changes in recent sediments of a small and shallow lake (Lake Pusty Staw, northern Poland). Journal of Paleolimnology 33: 313-325.

Urbański J., Kryla-Straszewska L. 2010. Monitoring i modelowanie jezior w systemach geoinformacyjnych. In: Z. Zwoliński (ed.) GIS - woda $w$ środowisku. Bogucki Wyd. Naukowe, Poznań: 121-146.

Wesołowski P., Brysiewicz A., Gałczyńska M. 2014. Zmiany stężenia tlenu i temperatury $\mathrm{w}$ warunkach różnych głębokości wody w śródpolnym oczku wodnym. Woda-Środowisko-Obszary Wiejskie 14,4: 135-144.

Wicik B. 1992. Budowa i funkcjonowanie systemów krajobrazowo-geochemicznych środkowego Mazowsza. Prace i Studia Geograficzne 13: 91102.
Wicik B., Więckowski K. 1991. Osady jezior „Na Jazach” w Kotlinie Płockiej - warunki ich akumulacji oraz rola w rekonstruowaniu i prognozowaniu przekształceń środowiska naturalnego. Przegląd Geograficzny 43,1/2: 57-76.

Więckowski K. 2009. Zagadnienia genezy, wieku i ewolucji jezior poszczególnych regionów Polski w świetle badań ich osadów dennych. Studia Limnologica et Telmatologica, Supplementum 1: 29-72.

Wojciechowski A. 1990. Analiza litofacjalna osadów Jeziora Gardno. Wyd. Nauk. UAM, Seria Geografia, 49.

Wolfe A.P., Hobbs W.O., Birks H.H., Briner J.P., Holmgren S.U., Ingólfsson O., Kaushal S., Miller G.H., Pagani M., Saros J.E., Vinebrooke R.D. 2013. Stratigraphic expressions of the HoloceneAntropocene transition revealed in sediments from remote lakes. Earth-Science Reviews 116: 17-34.

Woszczyk M., Spychalski W. 2007. Czynniki czasowej zmienności zawartości wybranych metali ciężkich w osadach Jeziora Sarbsko (Nizina Gardnieńsko-Łebska) na tle genezy zbiornika. Ochrona Środowiska $i$ Zasobów Naturalnych 31: 485-497.

Woszczyk M., Cieśliński R., Spychalski W. 2009. Geochemistry of surface sediments of a coastal Lake Sarbsko (Northern Poland). Studia Quaternaria 26: 41-53.

Zgłobicki W. 2010. Metody geochemiczne i radiochemiczne w badaniach dynamiki procesów stokowych. Prace i Studia Geograficzne 45: 105-124. 